Jurnal Ilmu Ilmu Agribisnis: Journal of Agribusiness Science, 9(3), Agustus 2021

\title{
SIKAP DAN FAKTOR-FAKTOR YANG MEMENGARUHI PEMBELIAN KONSUMEN TERHADAP ROTI KAMURA BAKERY DI KOTA BANDAR LAMPUNG
}

\author{
(Attitude of Consumers and Factors Affecting the Purchase of Bread at \\ Kamura Bakery in Bandar Lampung City)
}

Ria Devita, Wuryaningsih Dwi Sayekti, Rabiatul Adawiyah

\begin{abstract}
Jurusan Agribisnis, Fakultas Pertanian, Universitas Lampung, Jl. Prof. Dr. Soemantri Brodjonegoro No. 1
Bandar Lampung 35145. E-mail: wuryaningsih.dwisayekti@fp.unila.ac.id
\end{abstract}

\begin{abstract}
This study aims to analyze the attitude of consumers toward the purchase of Kamura Bakery bread in Bandar Lampung City, the purchase pattern, and the factors that influence the number of bread purchased. This research was conducted at Kamura Bakery Sukarame branch in Bandar Lampung City. The research method is a survey with accidental sampling technique. Respondents were 60 Kamura Bakery consumers who had bought/consumed Kamura Bakery at least once in the last one month. The research data are analyzed using Fishbein Multi-attribute analysis, descriptive statistics, and multiple linier regression analysis. Data collection was conducted in June - July 2020. The results showed that the consumers bought bread at Kamura Bakery mostly because of the taste. The highest amount of Kamura Bakery's bread purchased was chocolate flavor, the average number purchased was 28 pieces per household monthly, and the average frequency was seven times a month. The price of sweetened condensed milk and household income have a significantly negative effects on the number of purchase, while the number of family members has a significant positive effect on the number of bread purchased.
\end{abstract}

Key words: bread, consumer attitude, purchasing factors, purchasing patterns

\section{PENDAHULUAN}

Industri makanan dari waktu ke waktu mengalami perkembangan yang sangat pesat. Perkembangan yang pesat pada industri makanan mengakibatkan persaingan industri makanan saat ini hingga dikemudian hari bukanlah hal yang mudah. Industri makanan merupakan jumlah industri terbanyak dibandingkan dengan industri minuman dengan jumlah 277 industri pada tahun 2016 (BPS 2019).

Roti menjadi makanan penghasil energi yang banyak dikonsumsi oleh masyarakat Provinsi Lampung. Hal ini ditunjukkan dengan meningkatnya rata-rata konsumsi roti masyarakat Provinsi Lampung pada tahun 2017 ke 2018 sebesar 2,34 persen (BPS 2018).

Kebutuhan akan roti di kota-kota besar terkait dengan tingkat kesibukan masyarakatnya. Semakin tinggi tingkat kesibukannya maka semakin besar pula kebutuhan masyarakat terhadap roti. Hal tersebut dikarenakan roti menjadi salah satu makanan yang praktis tanpa memerlukan persiapan yang lama dalam mengonsumsinya dan mengandung zat gizi yang baik.
Bisnis yang memiliki omset penjualan yang sangat menguntungkan dan menjanjikan bagi para pelaku usaha yaitu industri roti. Hal ini terjadi karena meningkatnya daya beli masyarakat terhadap roti.

Industri roti merupakan industri makanan yang perkembangannya sangat pesat. Roti menjadi makanan dengan bahan utama tepung terigu dan air yang diolah dengan cara dipanggang (Pribadi, Alam dan Effendy 2017). Roti menjadi makanan yang sudah lama dikenal dunia sehingga dijadikan sebagai makanan pokok di banyak negara barat.

Menurut hasil survei pola konsumsi penduduk yang dilakukan oleh BPS pada tahun 2015-2018, konsumsi roti penduduk di Provinsi Lampung mengalami peningkatan terus menerus sebesar 0,41 persen. Kebutuhan konsumsi roti yang semakin meningkat menjadi peluang bagi masyarakat dalam berbisnis roti.

Saat ini mulai banyak berkembang bakery skala kecil di Kota Bandar Lampung yang menjadikan bisnis ini menjadi sebuah bisnis yang menjanjikan. Salah satu bisnis bakery skala kecil yang sedang berkembang saat ini di Kota Bandar Lampung yaitu 
Kamura Bakery yang berjualan di pinggir jalan dengan memanfaatkan tenda-tenda kecil. Kamura Bakery mengalami peningkatan penjualan yang signifikan dari tahun 2017 hingga 2018 sebesar 25,71 persen. Peningkatan penjualan yang terjadi dapat menggambarkan perilaku konsumen dalam membeli dan mengonsumsi Kamura Bakery.

Perilaku konsumen merupakan perilaku yang ditunjukkan oleh konsumen dalam menggunakan, menilai, mencari, menukar, mengatur barang atau jasa yang dianggap mampu memuaskan kebutuhan konsumen (Nugroho 2003). Harga, kualitas, fungsi atau barang menjadi keputusan yang difikirkan dahulu oleh konsumen saat membeli suatu produk. Perilaku konsumen merupakan kegiatan mempertimbangkan, memikirkan, dan mempertanyakan barang sebelum membeli.

Sikap konsumen menjadi hal penting yang akan mempengaruhi konsumen dalam melakukan keputusan pembelian. Sikap konsumen tersebut yang akan mempengaruhi pola pembelian. Pola pembelian tersebut dapat tergambarkan dari pembelian yang dilakukan secara terus menerus yang dianalogikan dengan pola konsumsi.

Pola pembelian konsumen dalam penelitian ini yang dicerminkan pada jumlah, jenis dan frekuensi. Jumlah pembelian roti Kamura Bakery yang dilakukan konsumen dapat dipengaruhi oleh beberapa faktor. Faktor-faktor yang mempengaruhi permintaan adalah harga barang itu sendiri, harga barang lain, pendapatan rumah tangga, jumlah anggota keluarga dan selera. Berdasarkan uraian yang telah dijelaskan, maka penelitian ini bertujuan menganalisis sikap konsumen, pola pembelian, dan faktor-faktor yang memengaruhi pembelian roti Kamura Bakery.

\section{METODE PENELITIAN}

Metode survei menjadi metode penelitian yang digunakan dalam penelitian ini. Penelitian ini dilakukan di Kamura Bakery Cabang Sukarame Kota Bandar Lampung. Pengambilan data dilakukan pada bulan Juni sampai dengan Juli 2020.

Pengambilan sampel pada penelitian ini dilakukan dengan Accidental Sampling yaitu teknik pengambilan sampel yang dilakukan secara kebetulan kepada konsumen yang sedang membeli roti Kamura Bakery dan bersedia diwawancara dengan panduan kuesioner.
Penentuan jumlah sampel dalam penelitian ini berdasarkan teori penentuan jumlah sampel menurut Maholtra (2005) yaitu banyaknya jumlah sampel diperoleh sekurang-kurangnya 4 sampai 5 kali jumlah variabel yang ada. Jumlah variabel yang dianalisis pada penelitian ini adalah 8 variabel/atribut, sehingga dapat diketahui jumlah sampel yang digunakan pada penelitian ini cukup 40, namun yang diteliti sebanyak 60 orang karena diharapkan semakin banyak sampel dapat merepresentasikan konsumen roti Kamura Bakery.

Kriteria sampel (konsumen) pada penelitian ini adalah sudah pernah membeli/mengonsumsi roti Kamura Bakery, mengonsumsi roti Kamura Bakery minimal 1 kali dalam sebulan terakhir, konsumen rumah tangga dan bersedia diwawancarai secara langsung menggunakan kuesioner.

Data yang digunakan pada penelitian ini terdiri dari data primer dan sekunder. Data primer diperoleh melalui pengamatan langsung dan wawancara kepada produsen dan konsumen di Kamura Bakery.

Wawancara kepada produsen terkait dengan sudah berapa lama membuka Kamura Bakery, perkembangan volume penjualan roti Kamura Bakery dan lokasi cabang Kamura Bakery. Wawancara kepada kosumen terkait dengan identitas responden, jumlah pembelian roti, frekuensi pembelian, jenis varian rasa, tingkat kepentingan atribut roti dan tingkat kepercayaan atribut roti Kamura Bakery. Pengamatan secara langsung untuk melihat keadaan di lapangan seperti kondisi Kamura Bakery, proses penjualan dan lokasi pemasaran.

Data sekunder dikumpulkan dari catatan Kamura Bakery, seperti data jumlah penjualan, serta data dari pustaka, studi literatur lain yang berhubungan dengan penelitian serta lembaga terkait seperti Badan Pusat Statistik Kota Bandar Lampung.

Sikap konsumen dianalisis menggunakan model multiatribut Fishbein. Model multiatribut Fishbein menjelaskan adanya salience of attributes. Atribut sikap dalam penelitian ini terdiri dari rasa, harga, tekstur, lokasi pembelian, pelayanan dan label halal.

Secara matematik atribut sikap dapat dijelaskan dengan rumus berikut:

$\mathrm{Ao}=\sum_{\mathrm{i}=1}^{\mathrm{n}}$ ei.bi 
Tabel 1. Hasil uji validitas dan reliabilitas untuk tingkat kepentingan atribut roti dan tingkat kepercayaan atribut roti Kamura Bakery.

\begin{tabular}{cccccc}
\hline & & \multicolumn{2}{c}{ Tingkat Kepentingan } & \multicolumn{2}{c}{ Tingkat Kepercayaan } \\
\cline { 3 - 6 } No & $\begin{array}{c}\text { Variabel } \\
\text { indikator }\end{array}$ & $\begin{array}{c}\text { Roti } \\
\text { Corrected Item- } \\
\text { Total Correlation }\end{array}$ & $\begin{array}{l}\text { Cronbach's } \\
\text { Alpha }\end{array}$ & $\begin{array}{l}\text { Corrected Item- } \\
\text { Total } \\
\text { Correlation }\end{array}$ & $\begin{array}{l}\text { Cronbach's } \\
\text { Alpha }\end{array}$ \\
\hline 1 & Rasa & 0,44 & 0,72 & 0,56 & 0,77 \\
2 & Harga & 0,54 & 0,58 & \\
3 & Tekstur & 0,25 & 0,34 & \\
4 & Lokasi Pembelian & 0,36 & 0,53 & \\
5 & Pelayanan & 0,53 & 0,73 & \\
6 & Label Halal & 0,63 & 0,39 & \\
\hline
\end{tabular}

Keterangan:

Ao $\quad=$ Sikap keseluruhan konsumen terhadap atribut Kamura Bakery

bi $\quad=$ Kekuatan kepercayaan atribut Kamura Bakery

ei $\quad=$ Evaluasi terhadap atribut Kamura Bakery

$\mathrm{n} \quad=$ Atribut yang relevan

Pengukuran skor tingkat kepentingan dan kepercayaan konsumen diukur menggunakan skala likert dengan rentang skala dari 1 sampai 5 . Sebelum dilakukan penelitian, kuesioner yang digunakan diuji validitas dan reliabilitasnya. Uji validitas dan reliabilitas bertujuan untuk mengetahui ketepatan kuisioner yang dilakukan pada 30 responden dari seluruh responden dalam penelitian.

Menurut Ghozali (2011) nilai validitas untuk menyatakan suatu kuesioner baik apabila nilai korelasi "corrected item" dengan "total correlation" lebih dari 0,2 , sedangkan nilai reliabilitas yang menyatakan kuesioner tersebut reliabel dengan nilai Cronbach Alpha lebih dari 0,7 (Sugiyono 2016). Hasil uji validitas dan reliabilitas tingkat kepentingan dan tingkat kepercayaan atribut roti Kamura Bakery dapat dilihat pada Tabel 1 .

Pola pembelian dianalisis dengan menggunakan analisis statistik deskriptif. Analisis ini dilakukan dalam menganalisis data secara deskriptif atau menggambarkan data yang diperoleh. Analisis statitik deskriptif bertujuan untuk mendeskripsikan atau menggambarkan data dalam setiap variabel yang dapat dilihat dari nilai minimum, maksimum, rata-rata (mean), dan standar deviasi (Ghozali 2011).
Pola pembelian konsumen dalam penelitian ini yang dicerminkan pada jumlah pembelian roti Kamura Bakery, jenis varian rasa roti Kamura Bakery dan frekuensi pembelian roti Kamura Bakery. Hal ini sejalan dengan penelitian Juwita, Sayekti, Indriyani (2015) yang menyatakan bahwa pola pembelian dapat digambarkan dari jenis, jumlah, dan frekuensi pembelian bumbu instan kemasan.

Analisis regresi linier berganda digunakan untuk mengetahui hubungan variabel bebas $(\mathrm{X})$ dengan variabel terikat $(\mathrm{Y})$ yang diturunkan dari teori permintaan. Faktor-faktor yang memengaruhi jumlah pembelian roti Kamura Bakery di Kota Bandar Lampung adalah harga roti Kamura Bakery, harga barang lain yaitu barang subtitusi (harga roti merek lain), dan barang komplementer (harga teh, harga susu kental manis, harga kopi bubuk), pendapatan rumah tangga, jumlah anggota keluarga dan selera.

Pada penelitian ini variabel barang lain (teh, susu kental manis dan kopi bubuk) ditentukan berdasarkan kebiasaan masyarakat dalam mengonsumsi roti, yang mana masyarakat biasanya mengonsumsi roti bersamaan dengan meminum teh, susu kental manis, dan kopi bubuk. Model persamaan regresi yang digunakan adalah:

$$
\begin{array}{r}
\mathrm{Y}= \\
\alpha+\beta_{1} \mathrm{X}_{1}+\beta_{2} \mathrm{X}_{2}+\beta_{3} \mathrm{X}_{3}+\beta_{4} \mathrm{X}_{4}+\beta_{5} \mathrm{X}_{5}+\beta_{6} \mathrm{X}_{6}+ \\
\beta_{7} \mathrm{X}_{7}+\beta_{8} \mathrm{D}+\mathrm{e} \ldots \ldots \ldots \ldots \ldots \ldots \ldots \ldots \ldots \ldots \ldots \ldots \ldots \ldots \ldots \ldots \ldots \ldots \ldots \ldots \ldots \ldots \ldots \ldots
\end{array}
$$

\section{Keterangan:}

$\mathrm{Y} \quad=$ Jumlah Pembelian (buah)

$\alpha \quad=$ Konstanta

$\beta_{i}, d_{i}=$ Koefisien regresi

$X 1 \quad=$ Harga roti Kamura Bakery (Rp/potong)

$\mathrm{X} 2=$ Harga roti merek lain (Rp/potong) 
Tabel 2. Skor evaluasi (ei), kepercayaan (bi) dan sikap (Ao) hasil penilaian responden terhadap roti Kamura Bakery di Kota Bandar Lampung

\begin{tabular}{lllll}
\hline \multirow{2}{*}{$\begin{array}{c}\mathrm{N} \\
\mathrm{o}\end{array}$} & \multirow{2}{*}{ Atribut } & \multicolumn{2}{c}{$\begin{array}{c}\text { Evaluas } \\
\mathrm{i}\end{array}$} & \multicolumn{2}{c}{$\begin{array}{c}\text { Roti Kamura } \\
\text { Bakery }\end{array}$} \\
\cline { 3 - 5 } & & (ei) & (bi) & (ei.bi) \\
\hline 1 & Rasa & 4,42 & 4,47 & 19,73 \\
2 & Harga & 4,33 & 4,30 & 18,63 \\
3 & Tekstur & 4,30 & 4,22 & 18,13 \\
4 & Lokasi & 4,13 & 4,25 & 17,57 \\
& Pembelian & & & \\
5 & Pelayanan & 4,30 & 4,05 & 17,42 \\
6 & Label Halal & 4,27 & 4,32 & 18,42 \\
\hline Jumlah (Ao) & & & 109,89 \\
\hline
\end{tabular}

$X 3=$ Harga teh $(\mathrm{Rp} / \mathrm{kg})$

$X 4=$ Harga susu $(\mathrm{Rp} / \mathrm{kg})$

$\mathrm{X} 5=$ Harga kopi $(\mathrm{Rp} / \mathrm{kg})$

$\mathrm{X} 6=$ Pendapatan rumah tangga (Rp/bulan)

$\mathrm{X} 7=$ Jumlah anggota keluarga (jiwa)

$D \quad=$ Selera (sikap konsumen)

$D_{1}=0$ (Tidak Suka ) $D_{1}=1$ (Suka)

e $\quad=$ Error

\section{HASIL DAN PEMBAHASAN}

\section{Karakteristik Konsumen}

Karakteristik konsumen dalam penelitian ini didasarkan pada jenis kelamin, usia, pendidikan terakhir, pekerjaan, dan pendapatan. Konsumen Kamura Bakery sebagian besar berjenis kelamin perempuan $(60 \%)$ dengan rentang usia yang paling banyak pada kelompok $20-31$ tahun (35\%) dari total 60 responden.

Konsumen roti Kamura Bakery sebagian besar berpendidikan Sarjana (S1) berjumlah 25 orang. Konsumen yang berpendidikan sarjana pada umumnya memiliki pendapatan dan pengetahuan yang lebih baik dibandingkan dengan konsumen yang memiliki pendidikan lebih rendah.

Pekerjaan konsumen pada penelitian ini beragam antara lain karyawan, PNS, wiraswasta, dan ibu rumah tangga. Pekerjaan konsumen paling banyak adalah karyawan sebanyak 20 orang $(33,33 \%)$. Pendapatan rumah tangga konsumen roti Kamura Bakery sebagian besar berkisar Rp4.000.000,00Rp6.999.000,00 per bulan dengan rata-rata pendapatan sebesar Rp6.230.000,00 per bulan.

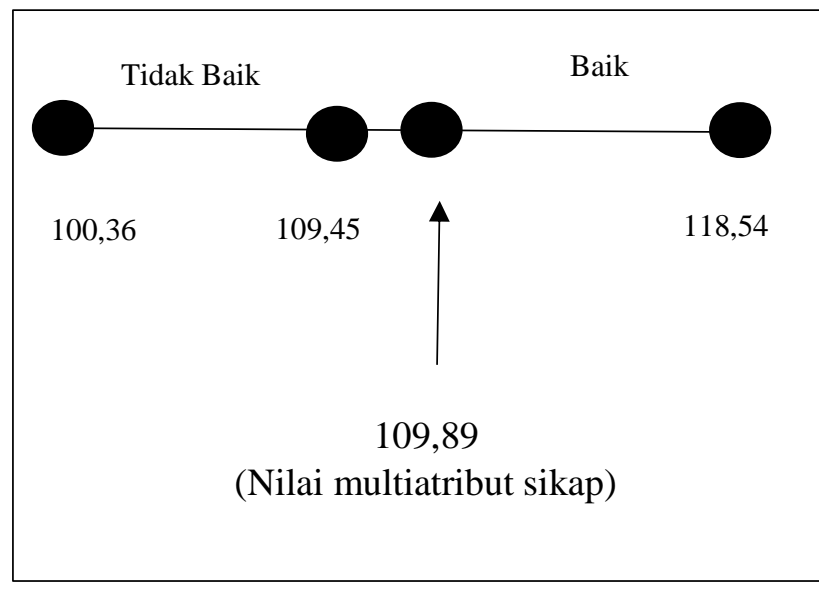

Gambar 1. Skala multiatribut sikap konsumen terhadap roti Kamura Bakery

\section{Sikap Konsumen}

Sikap konsumen menjadi salah satu faktor penting yang dapat memengaruhi keputusan konsumen dalam melakukan pembelian (Sumarwan 2015). Sikap konsumen dalam penelitian ini direfleksikan dengan selera konsumen.

Hasil penelitian terkait sikap konsumen roti Kamura Bakery secara rinci dapat dilihat pada Tabel 2 . Hasil dari evaluasi tingkat kepentingan konsumen (ei) menunjukkan bahwa atribut rasa yang dianggap sangat penting oleh konsumen dengan skor 4,42. Sejalan dengan penelitian yang dilakukan Andela, Endaryanto dan Adawiyah (2020) yang menyatakan atribut rasa pada pie pisang dinilai sangat penting oleh konsumen.

Kepercayaan konsumen terhadap atribut roti akan mempengaruhi sikap konsumen dalam melakukan pembelian roti Kamura Bakery. Hasil penilaian tingkat kepercayaan konsumen roti Kamura Bakery diperoleh skor tertinggi yaitu atribut rasa sebesar 4,47. Sejalan dengan penelitian Pratama, Indriani, dan Endaryanto (2017) yang menyatakan bahwa atribut rasa pada rumah makan MP Asli Hang Dihi dan rumah makan Ibu Safe'i menunjukkan skor nilai tertinggi.

Skor Multiatribut sikap konsumen yang diperoleh sebesar 109,89. Atribut rasa memperoleh skor tertinggi yaitu sebesar 19,73, Hal ini sejalan dengan penelitian Marbun, Priyono, dan Suryanti (2015) yang mendapatkan bahwa skor atribut rasa memperoleh skor tertinggi, sedangkan atribut pelayanan memperoleh skor terendah yaitu sebesar 17,42 . 
Tabel 3 Hasil analisis regresi berganda faktor-faktor yang mempengaruhi pembelian konsumen terhadap roti Kamura Bakery di Kota Bandar Lampung

\begin{tabular}{lccc}
\hline \multicolumn{1}{c}{ Variabel } & Coefficient & Prob & VIF \\
\hline Konstanta (C) & 33,14 & 0,09 & NA \\
Harga roti Kamura Bakery (X1) & 0,00 & 0,96 & 1,18 \\
Harga roti merek lain (X2) & 0,00 & 0,20 & 1,21 \\
Harga teh (X3) & 0,00 & 0,34 & 1,13 \\
Harga susu kental manis (X4) & $-0,000361^{* *}$ & 0,03 & 1,14 \\
Harga kopi bubuk (X5) & 0,00 & 0,58 & 1,27 \\
Pendapatan rumah tangga (X6) & $-0,000002^{* * *}$ & 0,01 & 1,32 \\
Jumlah Anggota Keluarga (X7) & $6,58^{* * *}$ & 0,00 & 1,40 \\
Selera (D) & 4,35 & 0,19 & \\
\hline R-squared & 0,62 & & \\
Adjusted R-squared & 0,56 & & \\
F hitung & 10,38 & 0,00 & \\
\hline
\end{tabular}

** = nyata pada tingkat kepercayaan $95 \%$

$* * *$ = nyata pada tingkat kepercayaan $99 \%$

Skor sikap konsumen pada penelitian ini dibagi menjadi dua rentang skala yaitu sikap konsumen baik dan sikap konsumen tidak baik terhadap roti Kamura Bakery. Penentuan skala sikap konsumen dirujuk berdasarkan penelitian yang dilakukan oleh Marbun, Priyono, dan Suryanti (2015) yang menganalisis sikap terhadap pancake durian produksi Celebrity Pancake di Kota Bengkulu.

Berdasarkan Gambar 1, skala sikap ditentukan dengan hasil selisih antara total perkalian skor tertinggi ei dan bi dengan total perkalian skor terendah ei dan bi yang kemudian dibagi dua untuk mengetahui nilai tengah pada skala. Sikap konsumen terhadap roti Kamura Bakery berada pada katagori baik. Hal ini sejalan dengan penelitian Frisdinawati dan Priyono (2012) yang mendapatkan bahwa nilai sikap total konsumen terhadap paket donat Surya Bakery di Kota Bengkulu berada pada katagori baik.

\section{Pola Pembelian}

Pola pembelian roti Kamura Bakery pada penelitian ini dianalisis secara deskriptif yaitu untuk melihat jumlah, jenis varian rasa dan frekuensi pembelian roti Kamura Bakery yang dilakukan konsumen. Jenis varian rasa pada penelitian ini terbagi menjadi empat rasa yaitu rasa coklat, keju, pisang dan srikaya.

Jumlah pembelian adalah banyaknya roti Kamura Bakery yang dibeli oleh konsumen selama satu bulan terakhir dengan berbagai jenis varian rasa yang ditawarkan untuk konsumen. Rata-rata jumlah konsumen dalam mengonsumsi roti Kamura Bakery varian rasa coklat dan keju sebanyak 8 potong per rumah tangga per bulan dengan jumlah pembelian varian rasa coklat lebih banyak.

Hal ini sejalan dengan penelitian Akram, Sahari dan Jaya (2016) yang mendapatkan bahwa varian rasa coklat paling banyak dibeli oleh konsumen. Ratarata jumlah pembelian varian rasa pisang dan srikaya sebanyak 6 potong per rumah tangga per bulan dengan jumlah pembelian varian rasa srikaya lebih banyak. Rata-rata pembelian roti Kamura Bakery per rumah tangga sebanyak 28 potong per bulan. Rata-rata frekuensi pembelian pada roti Kamura Bakery sebanyak 7 kali.

\section{Faktor-faktor yang Memengaruhi Pembelian Konsumen terhadap Roti Kamura Bakery}

Analisis regresi berganda dilakukan untuk melihat bagaimana pengaruh harga roti Kamura Bakery, Harga roti merek lain, harga teh, harga susu kental manis, harga kopi bubuk, pendapatan rumah tangga, jumlah anggota keluarga, dan selera terhadap jumlah pembelian roti Kamura Bakery apakah mempengaruhi secara positif atau negatif.

Jumlah pembelian yaitu banyaknya roti Kamura Bakery yang dibeli oleh konsumen. Konsumen roti Kamura Bakery paling banyak membeli roti Kamura Bakery dalam sebulan sebanyak 54 potong sedangkan paling sedikit yaitu 8 potong. Rata-rata jumlah pembelian konsumen roti Kamura Bakery yaitu 28 potong per bulan dengan varian rasa coklat, keju, pisang, dan srikaya. Varian rasa coklat dan keju memiliki rata-rata jumlah pembelian sebanyak 8 potong per rumah tangga per bulan, sedangkan 
varian rasa pisang dan srikaya memiliki rata-rata jumlah pembelian sebanyak 6 potong per rumah tangga per bulan.

Roti Kamura Bakery memiliki varian rasa bermacam-macam yaitu rasa coklat kulit nangka, keju, srikaya, pisang, abon, coklat moka, keju susu, coklat keju, spring, coklat susu, kelapa, lidah keju, kacang hijau, nanas, coklat mesis, kacang coklat, blueberry, dan lidah mesis. Pada penelitian ini varian rasa yang diteliti yaitu rasa coklat, keju, pisang, dan srikaya dengan pertimbangan paling banyak dibeli oleh konsumen.

Harga varian rasanya pun bermacam-macam dengan kisaran harga Rp3.500,00 hingga Rp5.000,00. Roti Kamura Bakery memiliki ratarata harga sebesar Rp4.108,00. Berdasarkan hasil penelitian varian rasa coklat paling banyak dibeli oleh konsumen dengan jumlah pembelian 476 potong dalam sebulan, sedangkan varian rasa pisang paling sedikit dibeli oleh konsumen roti Kamura Bakery dengan jumlah pembelian 345 potong dalam sebulan.

Konsumen tidak hanya mengonsumsi roti Kamura Bakery, namun juga mengonsumsi barang subtitusi dan barang komplementer lainnya. Barang substitusi adalah barang yang dapat menggantikan fungsi dari barang lain secara sempurna. Barang subtitusi pada penelitian ini adalah roti merek lain dengan rata-rata harga sebesar Rp4.546,00.

Roti merek lain pada penelitian ini masih satu "level" dengan roti Kamura Bakery yang terdiri dari Okta Bakery, Zahra Bakery, YM Bakery, AA Bakery, Brilian Bakery, Lakita Bakery, Jaya Bakery, Roman Bakery, Lens Bakery, 3R Bakery, Kembar Bakery, Emco Bakery, Nick's Bakery. Roti merek lain ini memiliki harga berkisaran Rp.2000,00 hingga Rp3.000,00 untuk roti yang dijual di warung dan Rp3.500,00 hingga Rp6.000,00 untuk roti yang dijual di toko dan standstand di tepi jalan.

Dipilihnya roti merek lain ini didasari karena kualitas dari roti merek lain ini tidak terlalu jauh dengan kualitas roti Kamura Bakery sebagai variabel utama dalam penelitian ini, dari hal rasa, harga, kemasan dan pelayanan masih bisa bersaing dengan roti Kamura Bakery. Harga termahal roti merek lain yaitu sebesar Rp6.000,00 dan termurah yaitu sebesar Rp2.000,00

Barang komplementer adalah suatu barang yang digunakan bersama-sama dengan barang-barang yang lain. Barang komplementer pada penelitian ini adalah harga teh dengan rata-rata harga sebesar Rp149.789, harga susu kental manis dengan ratarata harga sebesar Rp30.720,00, dan harga kopi bubuk dengan rata-rata harga sebesar Rp59.377,00.

Pendapatan rumah tangga adalah sejumlah uang yang diterima oleh seseorang sebagai gaji dari pekerjaan yang dikerjakannya. Pendapatan rumah tangga pada penelitian ini per bulan paling tinggi sebesar Rp10.000.000,00 dan paling rendah sebesar Rp1.000.000,00. Pendapatan rumah tangga pada penelitian ini sebagian besar konsumen merupakan masyarakat dengan katagori pendapatan menengah yaitu memiliki rata-rata pendapatan sebesar Rp6.230.000,00 per bulan.

Semakin banyak anggota rumah tangga maka akan mempengaruhi tingkat pembelian roti Kamura Bakery. Jumlah anggota rumah tangga pada penelitian ini paling banyak yaitu 7 orang dan paling sedikit yaitu 2 orang. Rata-rata jumlah anggota rumah tangga pada penelitian ini adalah 4 anggota rumah tangga.

Selera adalah sebuah perasaan suka atau tidak suka yang dirasakan oleh konsumen ketika mengonsumsi sesuatu. Selera konsumen ditentukan dari hasil perkalian atribut tingkat kepentingan dan atribut tingkat kepercayaan masing-masing individu konsumen, hasil perkalian ini diasumsikan dengan skor terendah dan skor tertinggi.

Skor terendah diasumsikan saat konsumen memilih skor satu untuk semua atribut sikap yang ada sementara skor tertinggi diasumsikan saat konsumen memilih skor lima untuk semua atribut sikap. Berdasarkan asumsi tersebut didapat bahwa nilai terendah untuk penilaian selera adalah 36 dan nilai tertinggi adalah 900, dari hasil tersebut kemudian dihitung nilai tengahnya yaitu 468 untuk menentukan kategori selera dimana nilai 36-467 adalah konsumen dengan selera tidak suka $(D=0)$ dan nilai 468-900 adalah konsumen dengan selera $\operatorname{suka}(\mathrm{D}=1)$.

Berdasarkan perhitungan tersebut dapat terlihat bahwa konsumen yang tidak suka terhadap roti Kamura Bakery yaitu sebanyak 8 orang, sedangkan yang suka terhadap roti Kamura Bakery sebanyak 52 orang. Hal ini menunjukkan bahwa konsumen Kamura Bakery pada umumnya menyukai roti Kamura Bakery

Berdasarkan hasil penelitian nilai R-squared pembelian roti Kamura Bakery di Kota Bandar 
Lampung sebesar 0,61 yang artinya sebesar 61 persen variasi jumlah pembelian roti Kamura Bakery dapat dijelaskan oleh variabel-variabel bebas yang telah dimasukkan ke dalam model, sedangkan sisanya sebesar 39 persen dijelaskan oleh variabel lain yang tidak dimasukkan ke dalam model.

Nilai F-hitung dalam penelitian ini sebasar 10,37813 dengan tingkat kepercayaan 99 persen yang artinya secara bersama-sama variabel bebas berpengaruh nyata terhadap pembelian roti Kamura Bakery di Kota Bandar Lampung. Hasil regresi berganda pada penelitian ini dapat dilihat pada Tabel 3

Berdasarkan hasil regresi, terdapat tiga variabel yang berpengaruh nyata terhadap pembelian roti Kamura Bakery yaitu harga susu kental manis, pendapatan dan jumlah anggota keluarga. Harga susu kental manis berpengaruh nyata negatif dengan tingkat kepercayaan 95 pesen. Pembelian roti Kamura Bakery akan menurun pada saat harga susu mengalami kenaikan, karena konsumen sudah terbiasa mengonsumsi roti Kamura Bakery bersama dengan meminum susu kental manis. Hal ini sejalan dengan teori Daniel (2004) yang menjelaskan bahwa apabila kedua barang dipakai secara bersamaan, bila salah satu dari harga barang tersebut naik, akan mempengaruhi banyaknya konsumsi barang komplemennya.

Pendapatan rumah tangga berpengaruh nyata negatif terhadap jumlah pembelian roti Kamura Bakery dengan tingkat kepercayaan 99 persen, yang artinya setiap meningkatnya pendapatan, maka jumlah pembelian roti Kamura akan menurun. Hal ini sesuai dengan penelitian Setyawan (2006) yang mendapatkan bahwa variabel pendapatan berpengaruh nyata negatif terhadap peluang pembelian produk bakery tradisional. Sehingga dengan pendapatan yang lebih tinggi konsumen lebih berpeluang untuk membeli produk bakery moderen karena harga produk bakery modern lebih mahal.

Jumlah anggota keluarga bepengaruh nyata positif terhadap jumlah pembelian roti Kamura Bakery dengan tingkat kepercayaan 99 pesen, hal ini menunjukkan apabila jumlah anggota keluarga meningkat maka pembelian roti Kamura Bakery meningkat. Dalam melakukan pembelian suatu produk, masyarakat pada umumnya akan menyesuaikan kebutuhan dengan jumlah anggota keluarganya. Hasil ini tidak sejalan dengan penelitian Sutrisyo dan Tecoalu (2016) yang menyimpulkan bahwa variabel yang berpengaruh nyata terhadap pembelian Kue Sorabi Rengasdengklok adalah citra merek, kualitas produk, dan lokasi.

\section{KESIMPULAN}

Sikap konsumen terhadap roti Kamura Bakery berada pada katagori baik. Konsumen roti Kamura Bakery menyukai roti Kamura Bakery dengan atribut yang paling disukai yaitu atribut rasa. Konsumen roti Kamura Bakery lebih banyak membeli varian rasa coklat. Rata-rata jumlah pembelian roti Kamura Bakery per rumah tangga sebanyak 28 potong per bulan dan rata-rata frekuensi pembelian roti Kamura Bakery sebanyak tujuh kali sebulan. Harga susu kental manis dan pendapatan rumah tangga berpengaruh nyata negatif terhadap jumlah pembelian roti Kamura Bakery, sedangkan jumlah anggota keluarga berpengaruh nyata positif terhadap jumlah pembelian roti Kamura Bakery.

\section{DAFTAR PUSTAKA}

Akram A, Sahari A, dan Jaya AI. 2016. Optimalisasi produksi roti dengan menggunakan metode Branch and Bound. Jurnal Ilmiah Matematika, $13 \quad$ (2): 107. https://bestjournal.untad.ac.id/index. php/JIT/article/download/7209/5799. November 2020.

Andela WE, Endaryanto T dan Adawiyah R. 2020. Sikap pengambilan keputusan dan kepuasan terhadap agroindiustri pie pisang di Kota Bandar Lampung. Jurnal Ilmu Ilmu Agribisnis, $8 \quad$ (2): $314 . \quad$ http://jurnal.fp. unila.ac.id/index.php/JIA/article/view/4070/2 965. [5 Agustus 2020]

BPS [Badan Pusat Statistik]. 2015. Pola Konsumsi Penduduk Provinsi Lampung Dalam Angka 2015. Badan Pusat Statistik Provinsi Lampung. Bandar Lampung. https://lampung.bps.go. $\mathrm{id} /$ publication/2016/09/20/cc02c6d58d0bba67 9dc3fb67/pola-konsu-msi-penduduk-provinsila mpung-2015. html. [20 Desember 2019].

BPS [Badan Pusat Statistik]. 2016. Pola Konsumsi Penduduk Provinsi Lampung Dalam Angka 2015. Badan Pusat Statistik Provinsi Lampung. Bandar Lampung. https://lampung.bps.go.id/publication/2017/04/13/75e26b75f0e0def47cb5 
b534/polakonsumsi-penduduk-provinsi

lampung-2016.html. [20 Desember 2019].

BPS [Badan Pusat Statistik]. 2017. Pola Konsumsi

Penduduk Provinsi Lampung Dalam Angka

2017. Badan Pusat Statistik Provinsi Lampung.

Bandar Lampung. https://lampung.bps.go.id/publication/2018/04/25/ae27fa7cdef55bafc892

baca/pola-konsumsi-penduduk-provinsilampung-2017.html. [20 Desember 2019].

BPS [Badan Pusat Statistik]. 2018. Pola Konsumsi Penduduk Provinsi Lampung Dalam Angka 2018. Badan Pusat Statistik Provinsi Lampung. Bandar Lampung. https://lampung.bps.go.id/publication/2019/04/29/5ffb5f7cb3479db127f 132d4/polakonsumsi-penduduk-provinsilampung-2018.html. [20 Desember 2019].

BPS [Badan Pusat Statistik]. 2019. Provinsi Lampung dalam Angka 2019. BPS Provinsi Lampung. Bandar Lampung. https://lampung.bps.go.id/publication/2019/08/16/801f3b93e755a417d7 e80da5/provinsilampung-dalam-angka2019.html. [20 Desember 2019].

Daniel M. 2004. Pengantar Ekonomi Pertanian. Bumi Aksara. Jakarta.

Frisdinawati D, dan Priyono BS. 2012. Analisis sikap dan perilaku konsumen terhadap produk donat paket Surya Bakery di Kota Bengkulu. Jurnal Agrisep, 11 (2): 199-200. https://media.neliti.com/media/publications/37-309-IDanali-sis-sikap-dan-perilaku-konsumenterhadap-pro-duk-donat-paket-suryabakerydi.pdf. [20 Januari 2020].

Ghozali I. 2011. Aplikasi Analisis Multivariate Dengan Program SPSS. Badan Penerbit Universitas Diponegoro. Semarang

Juwita A, Sayekti WD, dan Indriyani Y. 2015. Sikap dan pola pembelian bumbu instan kemasan oleh konsumen rumah tangga di Bandar Lampung. Jurnal Ilmu Ilmu Agribisnis. Volume 3 No 3 . https://jurnal.fp.unila.ac.id/index.php/JIA/article/view/1059/964. [28 November 2020]

Maholtra. 2005. Riset Penelitian. Gramedia Pustaka Utama. Jakarta
Marbun D, Priyono BS, dan Suryanti M. 2015. Analisis persepsi, sikap dan perilaku konsumen terhadap pancake durian (Studi kasus : Pancake durian produksi Celebrity Pancake). AGRISEP, (15) 2: 215-226. https://ejournal.unib.ac.id/-index.php/agrisep /article/view/839/734 [6 Oktober 2020].

Nugroho J. 2003. Perilaku Konsumen. Konsumen dan Implikasi untuk Strategi dan Penelitian Pemasaran. Prenada Media. Jakarta.

Pratama DY, Indriani Y, dan Endaryanto T. 2017. Sikap dan kepuasan konsumen terhadap konsumsi makanan pecel lele di Kota Bandar Lampung. Jurnal Ilmu Ilmu Agribisnis, 5 (2):202-203. http://jurnal.fp.unila.ac.id/index.php/JIA/article/view/1659/1 485. [10 November 2020]

Pribadi A, Alam MN dan Effendy. 2017. Analisis pendapatan usaha roti pada industri rumah tangga Aisyah Bakery di Kota Palu. e-J. Agrotekbis, 5 (4): 466 - 471. http://jurnal.untad-

.ac.id/jurnal/index.php/Agrekbis/article/view/ 10353. [25 Oktober 2019]

Setyawan H. 2006. Analisis sikap dan preferensi konsumen dalam pembelian produk bakery tradisional Kartika Sari Bakery Bandung. Skripsi. Fakultas Pertanian. Institut Pertanian Bogor. Bogor. https://docplayer.info/42482715-Analisis sikap-dan-preferensikonsumen-dalam-pembelian-produk-bakerytradision-al-kartika-sari-bakery-bandung-olehherisetya-wan-a.html. [6 September 2020]

Sugiyono. 2016. Metode Penelitian Kuantitatif, Kualitatif dan $R \& D$. PT Alfabet. Bandung

Sumarwan U. 2015. Perilaku Konsumen. Penerbit Ghalia Indonesia. Bogor

Sutrisyo HE, Tecoalu M. 2016. Faktor-faktor yang mempengaruhi keputusan pembelian Kue Sorabi Hijau Rengasdengklok. Jurnal Manajemen Bisnis. $11 \quad$ (1): 26. http://ejournal.ukrida.ac.id-

/ojs/index.php/MB/article/view/ 1175/1691. [2 Desember 2020 